\title{
Management of School Operational Assistance at Elementary School of Mojokerto Regency
}

\author{
Ambar Wahyu Kartikasari, Murtadlo, Ismet Basuki \\ Universitas Negeri Surabaya \\ Surabaya, Indonesia \\ ambarkartikasari16070845025@mhs.unesa.ac.id
}

\begin{abstract}
This research is based on postpositivism philosophy which is used to examine the condition of natural object and researcher as the key instrument. The results of this study are: 1) School Operational Assistance Fund is the only source of operational funding of schools coming from the central government, because of the funding sources obtained, its application and management requires good managerial skills as well. 2) the principal is an educational administrator, particularly in organizing, managing and evaluating finances from school funding sources, in which the three basic skills are indispensable in implementing financial management processes based on the School Operational Assistance Fund technical principles for the creation of operational activities effective.
\end{abstract}

Keywords-School Operational Assistance Fund; managerial skills; financial principles

\section{INTRODUCTION}

Based on researchers' observations in two primary schools in Indonesia, there was a phenomenon (issues) related to the management of School Operational Assistance (SOA) funds. These issues ranged from indications of misappropriation of SOA funds, ineffective management of BOS funds, allocation of SOA funds that were not in accordance with the needs of schools but based on the availability of funds (how much incoming budget). These issues arose because of the lack of understanding and attention to the progress and development of the quality of education in the school, and which concerned the actors here from making the emergence of such issues is none other than one of the most important members in the composition of the committee with spiced ideas from one of the teachers' councils.

The researchers took the location at two primary schools in Mojokerto because in the process of managing SOA funds are different from other schools. The bookkeeping process (administrative order) of finance is well organized and detailed starting from planning, implementation and evaluation. Specific planning here is the RKAS that contains the SOA which later as a form of accountability reporting. This is in line with the implementation of school-based management (SBM) as an implication of the implementation of school operational assistance that can not be separated and refers to technical guidance of school operational assistance in 2017. School's financial managerial implementation system especially the implementation of school operational assistance does not always run smoothly, there are some obstacles in which the principal must face and resolve. One of which is when the disbursement of SOA funds delayed or not in accordance with the specified time, whereas the real results of the operational assistance management is positive for the achievement of school goals. To overcome these obstacles, the principal should ideally have managerial skills as the basis for implementing tasks. One of which is in the management of school finances whose source of funding is in the form of school operational assistance.

The managerial skills referred to the theory by Robert L. Katz, a psychologist and an American organization as well as the initiator of the concept of managerial skills. The concept of managerial skills suggested by Robert L. Katz consists of three basic skills: technical skill, human relations skill, and conceptual skill [1]. In this case, the relationship between the financial management of all the processes of financial acceptance and expenditure requires managerial skills in such a way to produce an effective and efficient school financial condition in accordance with the finance principles. Based on the principal managerial competence, in performing the duties as a manager, the competency indicators which must be possessed and understood are: 1) planning the school, 2) expanding the school organization, 3 ) leading the school optimally, 4) managing change and development, 5) creating a school culture and climate, 6) managing teachers and staff, 7) managing facilities and infrastructure; 8) managing school and community relations; 9) managing learners; 10) managing curriculum development; 11) managing school finances in accordance with financial principles, 12) managing school administration, 13) managing school-specific service units, 14) managing school information systems, 15) utilizing advances in information technology, 16) monitoring, evaluating and reporting school program implementation [2].

Based on the above explanation, the researcher found that there was an interesting thing to study further, namely principal managerial skill in managing SOA. The skills were 
included in the principal managerial competence dimension with competency indicators capable of managing school finances in accordance with accountable, transparent, and efficient management principles. In this case, the researcher focused on the discussion of good financial resources management of school (especially SOA). Then, management indicators are: planning, implementating, and reporting (accountability) SOA fund allocation in those two schools. Researchers focused the research based on the management indicators because it is in accordance with the conditions (how the mechanism) of school financial management. The aspect of school financial planning is related to the adjusted budgeting to the existing budget with the implication in the form of RKAS containing SOA which refers to SOA technical guidelines of Fiscal Year 2017 without prejudice to the school financial principles in order to avoid misuse of SOA funds. Planning itself according to McCuen [3] is a basic function of management because it is indeed started from the components of organizing, staffing, directing, and controlling should also be planned first.

The implementation aspect (use) of the schools' finance refers to the law No. 48 of 2008 article 69 paragraph 3 [4], in which financial implementation mechanism of school with sources of finance derived from the government. In this case especially SOA program, it must be really in accordance with the predetermined plan (RKAS containing SOA in one budget year) and later this RKAS can be installed in bulletin board as a form to cultivate the trust of the community and students' parents for creating an effective and efficient financial condition.

The financial reporting aspect (accountability) of the schools refers to legislation which emphasizes that education funds obtained from the government and local government should be accounted for in accordance with the established provisions (Law No. 48 of 2008 article 79). The contents of the financial accountability report in this case especially SOA should include several components [5], including: 1) the amount of money received and issued, 2) book receipts and expenses, 3) transaction time, 4) various evidence of receipt and expenditure.

\section{METHOD}

This research is a kind of qualitative research which based on postpositivism philosophy, used to examine the condition of natural object, and the researcher as the key instrument. The data were collected through observation, interview, and documentation. The technique of data validation used triangulation (method and source). For data analysis, it was performed by data condensation, then present data, and make withdrawal conclusion. The results of this study emphasized on the meaning of generalization.

\section{A. Data Collection Techniques}

Data collection techniques in qualitative research conducted in a circular. Based on the procedure, the data collection method is done by using triangulation [6]. Three data collection techniques include: a) participant observation, b) depth interview, c) documentation.

\section{B. Quality Standards of the Data}

Based on characteristics of qualitative research, there are quality standards which should be fulfilled. Guba and Lincoln [7] stated that there are four standardized criteria to guarantee the trust or truth of the results of qualitative research. They are 1) credibility (internal validity), 2 dependability (reliability), 3) confirmability (objectivity), and 4) transferability (external validity).

Furthermore, Denzin and Lincoln [8] explain each component:

\section{1) Prolonged engagement}

Based on the extension of this observation it means that the relationship of the researcher with the source will be more rapport. It means that the more familiar (no longer distance), the more open, trust each other so that no information is hidden. Similarly to Stainback [9], he provides an understanding that relationships can be established and manifested based on the relationship of mutual trust and emotional closeness between two or more people.

Based on the extension of observations made by researchers, researchers follow all the school operational activities in educational institutions which selected for research, especially on the process of financial management of schools with funding sources of SOA. Researchers always tried to follow and saw the activities between the principal and the school treasurer during the management process.

\section{2) Persistent observation}

Observations were conducted continuously within a certain time so that the data obtained were real and deep (increase persistence in observation). Observation is a technique used to understand a more profound phenomenon. By having this technique, the researcher will be able to determine which aspects are important and which are not, and then focus on the aspects which relevant to the research focus. During the research, researchers always maintained good communication and relationship with the head of SDN Sumberkembar and head of SDN Seloliman in order to achieve the data needed for in accordance with the research focus.

\section{3) Triangulation}

Triangulation on credibility testing can be interpreted as checking data from various sources using various ways, and at various times. In this triangulation stage, there is triangulation of sources, triangulation of data collection techniques, and time [10]. In this study, researchers used triangulation of sources and triangulation of methods (data collection techniques). 


\section{4) Peer debrieffing}

This is performed by asking colleagues who do not participate in researching. The colleagues can discuss and ask about various things including the methods used, the temporary conclusions obtained by the researcher and the possibility of biases caused by the researcher.

\section{5) Referential adequacy chekcs}

This step is to track the suitability of all data analysis results; the more appropriate, the more reliable the results. The testing phase on the credibility of the data through reference adequacy checks is performed through deeper review of the data, especially related to the research focus.

\section{6) Member checks}

Member check is an activity of data checking process obtained by the researcher to the data provider. The purpose of holding a member check on research on principal managerial skills in managing SOA 2017 budget year is to find out how far data has been obtained in accordance with the data given by the provider.

\section{RESULTS AND DISCUSSION}

\section{A. Mechanism of Financial Planning in SOA Management}

The manufacture of all documents related to school financial planning of SDN Sumberkembar and SDN Seloliman Mojokerto, especially RKAS containing SOA, was in accordance with the SOA regulation. This can be perceived from the documentation obtained by researchers. RKAS was a plan to obtain educational funding from various sources of income and the composition of annual work program consisting of a number of routine activities as well as several other activities along with its financing plan details within one year of budget. This financing plan was integrated with the plan of receipt and expenditure. This RKAS was a guideline for financing the education in the schools until the management of financial administration was realized and also the principle of budgeting schools' revenues and expenditures. All collected funds were allocated to finance various school programs and activities which arranged on a priority scale. Moreover, all allocations of funds had to be realistic.

The above information defines financial management as a financial administration including records, planners, execution, accountability, and reporting. It can be simplified that financial management is a set of activities which governs school finance from school planning, bookkeeping, spending, supervision, and financial accountability.

\section{B. Implementation Mechanism in SOA Management}

Management of education finance is one of the substances of school management which will contribute in determining education operational activities in schools. Educational financial management activities in the school mechanism begin with creating a plan contained in the RKAS within a budget year. The RKAS is correct in accordance with the needs (priority) at each school. The purpose of preparing the RKAS is to ensure the implementation of SOA funds not deviate from the predetermined planned.

The implementation of SOA funds allocation at SDN Sumberkembar and SDN Seloliman basically covered all forms of outflow of school funds used for direct and indirect provision of education services. The financial expenditure at SDN Sumberkembar and SDN Seloliman referred to the predetermined plan. All financial expenditures in SDN Sumberkembar and SDN Seloliman had to refer to the components specified in the RKAS. In addition, the bookkeeping of income and outcome of SDN Sumberkembar and SDN Seloliman had to be performed carefully and transparently. Therefore, principals and school treasurers from SDN Sumberkembar and SDN Seloliman had to understand the regulations associated with the financial bookkeeping.

\section{The Financial Reporting Mechanism in SOA Management}

School revenues and expenditures had to be reported and accounted regularly in accordance with applicable regulations. Every income and expenditure had to be recorded in an orderly manner in accordance with applicable guidelines and regulations. Considering that most of the education funds in SDN Sumberkembar and SDN Seloliman were from the government through SOA, bookkeeping documents reports which must be prepared by SDN Sumberkembar and SDN Seloliman including (1) school plan and budget activities, (2) books (3) cash assistance books, (4) bank assistance books, (5) tax assistance books, (6) cash checks, (7) proof of expenses.

Reporting mechanisms for managing SOA at SDN Sumberkembar and SDN Seloliman through several procedures including: (1) realization of the use of funds for each source of funds, (2) recapitulation of BOS usage, (3) recording of services and handling public complaints, (4) assets, (5) reporting to the education office, (6) online reporting to the SOA page.

The above explanation is reinforced by Government Regulation No. 48 of 2008 article 79 [4] stating that education funds obtained from the government and local governments accounted for in accordance with the provisions of legislation. Accountability activities can be done monthly, every semester, or every completion of an activity. Based on applicable regulations, in general SOA fund reporting procedures include.

1. Accountability report submitted every quarter, semester and year.

2. Reports prepared with reference to general ledger (SOA $\mathrm{K}-3$ ), cash auxiliary book (SOA K-4), bank auxiliary book (SOA K-5) and tax aide book (SOA K-6) as well as supporting documents others as evidence.

3. Reports made for submission to district education offices are SOA K-2 format, SOA K-3, SOA K-4, SOA K-5, and SOA K-6. 
4. Reports that need to be made to be announced to the public are reports on the use of SOA funds (SOA-03 format).

\section{Principal's (Perception) Perception on School Finance} Principles in the Implementation of SOA Allocation

Government policy especially SOA funds is already familiar, but the implementation of the regulation always experiences innovation and development for the realization of quality education. SOA funds have a goal to minimize the dropout rate from primary to secondary education. If there is a child who still categorized in the school age, but not naturally status as a learner, other possibilities in addition to economic factors is due to not understanding how important the meaning of education in the future.

\section{CONCLUSION AND SUGGESTION}

\section{A. The Mechanism of Financial Planning in Managing SOA} Funds

The mechanism of school financial planning in managing SOA funds conducted by school principals in SDN Sumberkembar and SDN Seloliman has been referenced and according to SOA technical regulations which can be seen from the preparation of financial plans as stated in the school budget plan. The school's financial plan refers to the EDS outcomes which will become the priority program or plan of the school's needs. Preparation of school budget plan which has been performed by the head of SDN Sumberkembar and SDN Seloliman is in accordance with the provisions as follows.

1. RKAS contains income sources.

2. CTR contains a program / activity strategic and routine.

3. RKJM, CTR, and RKAS are prepared based on EDS results.

4. RKJM, RKT, and RKAS must be approved in teacher board meetings.

The procedure in preparing RKAS meeting about SOA in SDN Sumberkembar and SDN Seloliman is as follows.

1. Establish a RKAS compilation team.

2. Conducting situasinonal analysis.

3. Determine the one year goal.

4. Identify real challenges.

5. Develop a school plan.

6. Prepare a cost plan.

7. Implement the program implementation strategy.

8. Prepare program implementation strategy.

9. Prepare supervision plans for established teams and implementation of activities.

B. The Mechanism of Implementation (Utilization) in The Management of SOA Funds

The implementation mechanism of SOA funds allocation in SDN Sumberkembar and SDN Seloliman actually refers to the components in accordance with the provisions. The implementation of SOA funds should be basically in accordance with the plan or RKAS which made for one budget year. This can be seen in several documents as well as financial bookkeeping related to the management of SOA in SDN Sumberkembar and SDN Seloliman.

It is not justified that in implementing the allocation of SOA funds, a principal performs the task of treasury, in this case, especially the management of the SOA funds should be separated and properly understood between the task of the principal, ordinator, and the civic order so that there will be no imbalances or misunderstandings. It should be understood that in general the implementation of SOA funds at primary school level includes the following activities.

1. Library development.

2. Acceptance of new learners.

3. Learning and extracurricular activities.

4. Learning evaluation activities.

5. School management.

6. Development of teacher profession and education personnel, as well as development of school management.

7. Power subscriptions and services.

8. Maintenance and maintenance of school infrastructure.

9. Payment of honorarium. Purchase / maintenance of multimedia learning tools.

\section{Reporting Mechanism (Accountability) in BOS Management}

The reporting mechanism for accountability in the management of SOA funds in SDN Sumberkembar and SDN Seloliman both from the content of the report and its procedures based on the research can be concluded that the reporting of SOA funds allocation has really referred to and in accordance with SOA technical regulations. This can be seen in several procedures which implemented at SDN Sumberkembar and SDN Seloliman, such procedures including: (1) realization of use at each source, (2) recapitulation of realization of BOS usage, (3) recording of service and handling of public complaints, 4) asset reports, (5) reports to the education service, (6) online reporting to the SOA page.

The procedures will also be completed along with several documents (bookkeeping) to support the SOA funds management report, such documents as: (1) school activities and budget plans (RKAS), (2) general ledger books, (3) books cash auxiliaries, (4) bank auxiliary books, (5) tax aide books, (6) cash checks, (7) proof of expenses.

\section{REFERENCES}

[1] R. L. Katz, "Skills of an Effective Administrator.," Harv. Bus. Rev., 1955.

[2] P. M. P. N. R. Indonesia, "Nomor 13 Tahun 2007 tentang Standar Kepala Sekolah/Madrasah," Biro Huk. dan Organ. Dep. Pendidik. Nas., 2007.

[3] J. T. McCuen, "The Future and Long-Range Planning--Strategies for Change and Redirection.," 1974.

[4] P. P. No, "tahun 2008 tentang Pendanaan Pendidikan," Pemerintah RI, 48AD. 
[5] B. O. S. Tim Pengelola, "Buku Panduan Bantuan Operasional Sekolah," Depdiknas Dirjen Dikdasmen. Undang. Tentang Sist. Pendidik. Nas. Tahun, 2003.

[6] J. W. Creswell, Educational research: Planning, conducting, and evaluating quantitative and qualitative research. 2012.

[7] Y. S. Lincoln and E. G. Guba, "Effective evaluation," New York Jassey-Bass, 1985.

[8] N. K. Denzin and Y. S. Lincoln, The SAGE handbook of qualitative research. Sage, 2011

[9] S. Stainback and W. Stainback, Understanding \& Conducting Qualitative Research. ERIC, 1988.

[10] J. W. Creswell and D. L. Miller, "Determining validity in qualitative inquiry," Theory Pract., vol. 39, no. 3, pp. 124-130, 2000. 